Article

\title{
Growth Strategy of a Rural Business School: Sustainable Implementation of Online Studies
}

\author{
Bernt Arne Bertheussen (1)
}

School of Business and Economics, UiT-The Arctic University of Norway, 9037 Tromsø, Norway; bernt.bertheussen@uit.no; Tel.: +47-776-231-54

Received: 25 May 2020; Accepted: 23 June 2020; Published: 29 June 2020

check for updates

\begin{abstract}
This case study, which uses interventionist action research methodology, first describes key elements of the online business model which was implemented at a business school in Arctic Norway. The aim of the business model intervention was to create a growth in student influx. Next, the study examines the actual impact of the intervention in terms of number of online applicants over the last decade. The findings show that the online courses hit a "nerve" in the Norwegian market for higher education as now more than a thousand students, scattered all over the country, apply for admission. Thereafter, the study investigates why students choose to study online. The results disclose that the main motive for choosing online studies is that they better meet students' needs for different types of study flexibility. Finally, this research explores whether online studies cannibalizes the traditional campus model in a non-sustainable way. The findings show that online and traditional campus studies do not compete, but instead complement each other as they attract different target groups of students. Online studies serve as an essential channel for lifelong learning as the students were mainly well-educated women who worked full-time or part-time. Finally, strategic insights from the process of launching sustainable online studies by a rural business school are discussed.
\end{abstract}

Keywords: distance education; learner flexibility; dual business models; cannibalizing business models; interventionist action research

\section{Introduction}

Globally, the landscape of higher education is changing as there is an ongoing digital transformation of the sector [1,2]. In the United States, enrollments in distance education programs have continued to increase despite the decline in enrollments in higher education [3]. There are nearly five times as many undergraduate enrollments compared to graduate enrollments among students taking at least one online course [3]. New technology is pushing [4], at the same time as the market is pulling, institutions in a digital direction because more and more digitally competent students are demanding flexible education $[5,6]$. People want to study what they want, where they want, and when they have the time for it. It is this need for flexibility that the phenomenon of online education attempts to satisfy [7].

In Norway, the intention is that the entire population should have access to flexible lifelong learning. Thus, the white paper "Culture for quality in higher education", states that "society and working life is increasingly characterized by technological change. The use of digital technology leads to changes in just about every area of modern society and has, in a short time, reversed the rules of the game in various industries." [8] (p. 12). Furthermore, the Norwegian National Competence Policy Strategy for 2017-2021 points out that the higher education sector must respond to the needs of employment for knowledge and competence and develop study programs for lifelong learning [9]. Internationally, the development of massive online open courses has accelerated, and these courses aspire to offer online education on a large scale with no or minimal cost to students. These online courses may eventually threaten the business model of traditional universities [10]. 
Locally, in the wake of digital technology, new business models have emerged in organizations [11]. This study explores how a business school in Artic Norway, with a very limited local recruitment basis, managed to grow by developing an online business model, which was designed to work in parallel with the traditional campus model. The online model removed the importance of geographical distance and attracted students from all over the country. First, the study describes key elements of the online business model implemented at Campus Alta, which is one of four campuses at the School of Business and Economics, UiT The Arctic University of Norway. Next, the study examines the growth impact of the online business model in recent years. Third, the study investigates why students choose to study online. Finally, the study explores if the online business model cannibalized traditional campus studies and thus dampened net growth and overall sustainability.

\section{Theory}

The primary purpose of a business is to drive growth and performance while generating value for customers. A firm can achieve this goal through operating one or more business models. The business model concept describes the underlying logic by which a firm creates and captures value $[12,13]$. Teece [14] (p. 172) defines a business model as "the manner by which the enterprise delivers value to customers, entices customers to pay for value, and converts those payments to profit". Furthermore, a business model connects strategy formulation and implementation, as it explains how the strategic activities of a firm operate together [15]. Firms are today increasingly introducing dual or multiple business models as a basis for growth and diversification $[13,14,16,17]$. The strategic aim is to establish a unique bundle of business models that can deliver sustainable competitive advantages $[14,18]$.

Strategic diversification through launching different business models is about combining activities that efficiently relate to and mutually reinforce one another, thus forming a system of synergetic activities, as opposed to a collection of isolated activities [19]. Porter [19] argues that a firm's competitive strategy entails a deliberate choice of a specific set of activities aimed at delivering a unique mix of customer value. Accordingly, strategic fit across business models can enhance individual activities and create unique and hard-to-imitate resources and capabilities, which lead to enhanced performance [20].

When building business models, a firm must assess to which degree the models can share physical assets and technology. By sharing, the firm can harvest economics of scope and eliminate redundancies [21]. Moreover, a firm can create cross-business model synergies through sharing valuable knowledge and financial resources. Last but not least, multiple business models can help firms reduce risk by tapping into different revenue streams [22].

An additional business model may provide access to valuable assets that can strengthen the existing model [20]. For example, digital learning resources developed to support online learners, can be blended into traditional in-class campus courses and also strengthen the learning outcomes for students on campus [7]. However, the added costs of acquiring new resources may restrict a firm in developing new products and services [23]. Thus, there is a risk that a firm's historical investments in valuable resources and capabilities can constrain its willingness to adopt new business models.

Influential strategy scholars claim that competitive advantages are primarily based on a firm's ability to control valuable, unique, and scarce resources [24-26]. As a result, many firms focus their strategizing efforts on acquiring and protecting what they consider unique assets. However, when exploring a new business model, a firm exploits opportunities which tap into existing resources to achieve economies of scope and better capacity utilization [20]. Consequently, the new model utilizes resources and capabilities that are closely related to and adopted by the existing business model [27].

The purpose of business model diversification is to enable a firm to maximize the yield from existing resources while developing capabilities that enhance their value across multiple activities [20]. Accordingly, it is important to assess whether the new business model helps maximize the use of the current resource base, while at the same time meeting a new and important customer need [18]. If successful, the firm can generate cost efficiencies while also providing opportunities for risk reduction. 
Therefore, when developing a new business model, a firm needs to ensure that the model is linked to the company's existing distinctive capabilities [14,18].

Although the idea of cross-business-model synergies is appealing, implementation is not straightforward. Implementation issues also apply when it comes to harvesting intra-business-model complementarities [18]. Business model diversification does not always generate superior performance. Different business models can compete and conflict with one another, thus resulting in unsustainable cannibalization rather than creating synergies [20]. Therefore, a firm must examine the interrelationships across their business models rigorously and on a regular basis. In settings where a business model is not generating the synergies anticipated, managers must improve, streamline, or divest business models, and focus on strengthening the activities that are strategically most important [18]. The next section provides a description of the empirical context of this study.

\section{The Rural Empirical Context}

Norway is the northernmost country in Europe and is politically regarded as a social democratic country together with its neighboring countries Sweden, Finland, Denmark, and Iceland [28]. This implies, among other things, that higher education is mainly publicly funded and that students do not have to pay tuition fees when studying.

Finnmark is Norway's northernmost and easternmost region, with borders along Russia in the east (Pechengskij rajon in Murmanskaya oblast) and with Finland in the south (Finnish Lapland). In area, Finnmark is larger than Denmark and Norway's largest region $\left(48,631 \mathrm{~km}^{2}\right)$. At the same time, Finnmark has the smallest population of the country $(75,000)$. Finnmark is characterized by a tough Arctic climate and extreme distances. A very large proportion of the inhabitants $(80 \%)$ live far from the campus in Alta town.

\subsection{Background and Motives for Adding an Online Business Model}

The current business school at Campus Alta is the result of a merger between the University College of Finnmark (1994-2013) and the business school at UiT Campus Tromsø. The purpose of the former University College was nevertheless to provide competence enhancement to people throughout the whole Finnmark region. Contributing to education outside campus was also an important part of the social mission of the institution. Employees experienced the work as meaningful, and they personally identified with this mission. To fulfil the task, teachers physically travelled around the district and taught students who, for various reasons, could not get to campus. Decentralized teaching was arranged in Kirkenes, Vadsø, and other towns. In line with new technological opportunities, physical subject meetings were combined with audio/video conferences to reduce the traveling costs. Activities were financed by credits and from external sources. Off-campus activities were thus not funded through basic allocations from the authorities. Teaching was mainly carried out by the professional staff taking on projects in the form of extra teaching jobs. For the model to be financially sustainable, there was a need for more students or other strong additional funding.

The development of online studies at Campus Alta started in 2007. The motive was the same as before: contribute to raising the competence in the entire region. The same year, one of the most sought-after campus programs (Project Management) was offered online in an attempt to test out streaming/web TV. This experiment marked the start of an online delivery format for distance education at Campus Alta. The format was demanding for the information technology (IT) department, but it gave them the necessary experience and expertise on technology. In the early years, the technology was largely "home-made" by a very committed and dedicated employee at the IT department. The subject teachers also spent time to acquire expertise on what served as good teaching methodology online [29].

Faculty working with economics and management were regrouped in Campus Alta after the merger in 2013. Now, Campus Alta obtained new and more robust technology solutions (Mediasite). However, there were major problems. The reason was that the central IT department at UiT Campus Tromsø was not familiar with the extensive offering Campus Alta had of online education. In 2015, a 
studio was built for recording videos on the premises of Campus Alta. Now, the staff no longer needed to travel to Campus Tromsø to create teaching videos.

\subsection{Strategic Foundation of the Online Business Model}

For development processes to succeed, they should be strategically well rooted in the organization [30]. UiT discovered early on the opportunities to offer flexible education through digital technology. The strategy paper for the period 2009-2013 [31] (p. 4) stated that "The university shall be nationally leading and innovative in decentralized and web-based education, so that larger parts of the population of the region can be reached with relevant educational offers. Offers of flexible lifelong education are important for maintaining and updating the competence of the region." The strategic goal of developing flexible education was followed up by specific allowances, and in the years 2011-2014, more than 10 million Norwegian kroner (NOK) was allocated to various projects to stimulate the development of flexible online education [32].

\section{Materials and Methods}

This is an interventionist action research case study. There are many varieties of case studies, one of which is interventionist action research (IR) [33]. The IR approach is a member of the action research (AR) family that aims to increase the relevance of research [34]. The essence of interventionist research is researching where practice and theory meet. Drawing on Kurt Lewin's dictum of "One of the best ways to understand the world is to try to change it" [35] (p. xii), AR is today accepted as a complementary and significant research tool [36].

Carkhuff [37] (p. 163) defines an intervention when stating that: “ ... an intervention is both a response and an initiative. It is a response to a situation that defines a need. It is a response to a deficit or to what is not present. At the same time, it is an initiative to influence that situation-to fill in what is not present, to transform the deficits into assets. In short, an intervention is an attempt to make a difference". One of the most important reasons to conduct interventionist research is to overcome the weaknesses of research where subjects do not have to commit to action and create a future that they themselves must become a part of [34].

IR has many similarities with non-interventionist research as both aim to create a meaningful conceptualization of the phenomena they encounter in the field, at gaining an understanding of what is going on in the case and finally to develop explanations [34]. The theoretical targets include similar options and attempts toward theory contribution require translation of the findings to a more general level in both approaches. The major differences relate to the fact that an interventionist researcher is directly involved with something that is going on in the case and does not try to avoid having an effect. Instead, an intervention is applied as a research asset [36].

IR is a genre of applied research and has two outputs: a knowledge product for both researcher and practitioner and a practice product or intervention developed for problem solution [38]. The aim of IR is to effectively improve a real-life context through the development of interventions. This involves a coordinated effort of all participants who are actually experiencing the problem. There is no one particular research technique that is employed in the design and development phase of the intervention. Both quantitative and qualitative research are used.

The present interventionist case study applies a multi method research design [39]. Persons who have been central to the development process in different roles were interviewed in-depth: the campus manager, an online teacher/developer and the person being administratively responsible for the online studies. An interview guide was developed, which included the topics to be discussed. The guide was based on the theoretical perspectives and previous analysis of secondary data to make sure the context of the questions was understandable and relevant for the practitioners who were interviewed. The questions were formed very open. For example, one question was: "Can you tell me about the background and motives for engaging in online studies?" Another was: "What challenges have you faced in the process?" Moreover, questions were aimed at steering the conversation into the 
research questions without suggesting any direction of answers. For example, to enlighten RQ1 the question asked was: "Can you tell me about the key elements of the online model implemented at the campus?" Three in-depth interviews were conducted during the winter of 2019. Each interview lasted approximately $40 \mathrm{~min}$. Notes were taken while the interviews were taking place, and informal discussions were summarized in writing immediately after the meetings.

Data were gathered and analyzed concurrently by data reduction, and key information in sections based on the topics of the interview guide was also gathered. First, each case was treated singularly, gathering relevant primary and secondary data. When all cases were concluded, we searched for similarities and differences, and cross-case patterns that would shed light on the questions raised. As the data amount was not as voluminous, no data analysis software was considered necessary.

Moreover, the study gained access to secondary data from administrative systems of the business school. To answer whether the online business model cannibalizes the campus model, a questionnaire was submitted by a sms-link to 800 students who were active learners on online topics in 2018. These students made up the entire population of online students at Campus Alta last academic year. In the same survey, more information was obtained about the online learners and their motives for studying online. Students were informed about the purpose of the study and that the responses were anonymous. The questionnaire contained both closed- and open-answer options. The study received 80 responses $(10 \%)$.

The intervention in the present study is the online business model implemented at Campus Alta (RQ1). Next, the effect or impact of the intervention is measured by its growth in student influx (RQ2). Thereafter, key causes to the growth (effect) are investigated (RQ3); i.e., why students chose to study online. Finally, eventual negative secondary effects of the intervention are explored (RQ4); specifically, if online studies cannibalize traditional campus studies and thus makes the dual business model deployed less sustainable.

\section{Results}

This section presents empirical responses to the research questions raised in the introduction of the paper.

\subsection{What Were the Key Elements of the Online Business Model (RQ1)?}

The staff at Campus Alta has for years built and implemented an online business model, which has recruited online students in the local and national market for economic and management studies. The employees (teachers, technicians, and administrative staff) have achieved this through voluntary work, all-out efforts, and the smart use of scarce resources. Following Johnson et al. [40], key elements of the online business model are outlined in Table 1; that is, the model's value proposition, how values are created, key resources needed, and the key processes of the model. 
Table 1. Key elements of the online business model of Campus Alta *

Students' value proposition

Value creation for the institution

Students can gain credits free of charge by studying what they want, when they want, and where they want. The learning outcome depends completely on their own motivation and study effort.

A scalable digital teaching platform provides very low marginal costs per student [41]. Accordingly, the institution can make money from a large production of credits.

- The model requires state-of-the-art technology to produce high-quality live broadcasts and videos. There is a need for technically advanced expertise that has operational and emergency preparedness. The IT department must therefore be accessible.

Key resources

- The model needs an informative web platform with answers to frequently asked questions (FAQs), and a high-quality digital learning platform (LMS) (e.g., Canvas). Online pedagogical competence is an important teaching resource to tailor digital learning applications in the LMS.

- A web study always begins with a start-up gathering. Here the students are socialized, and they get a good academic start. At the gathering, groups are formed, and technical and professional guidance is provided [42]. Other issues that can contribute to a helpful online-based study and learning environment are also discussed.

- Web lectures that are streamed live and sent in recording, are supported and quality assured by administrative staff on an ongoing basis. This also applies to video productions. Furthermore, processes that structure the topics in the LMS are important [43].

- If a course uses group work as a learning activity, the students are divided into groups early on in the semester. When coursework is needed, it is necessary for the students to get started with these in a timely manner. It is better with several small course activities than a few large ones. It is also important to obtain an overview of the number of active students early in the semester in order to dimension the resource input.

Key processes

- Professional feedback is essential for students' learning [44]. Some coursework has automated correction, whereas others are approved by the subject teacher. Feedback can also be collective in that solution proposals are published that highlight problems and common mistakes.

- Local business mentors join forces with teachers in class or videos to link practice to theory. Thus, the students gain insight into established working life practices by skilled business actors [45]. The subject teacher links the industry actor's practice to theory in the syllabus. Business cases are used to create greater learning engagement [46]. Student cooperation is arranged on an online basis [47]. The exam format is adapted to the course's learning outcome descriptions and the learning activities [48]. 
Innovative business models can change industries and create spectacular growth for businesses [49]. Such a model consists of four distinct elements. It offers a good value proposition to customers, it creates profit for the enterprise, and it focuses on key resources and key processes that are critical to making the model work [14,40]. An online business model must thus contribute additional value to the institution through increased revenues or reduced costs. Furthermore, the organization must possess or develop key resources in the form of technology, expertise, services, and perhaps also a brand, which are necessary to meet the value proposition of the target group. Finally, the institution must have control over operating routines and processes so that it is able to deliver value to students on a digital platform. Such a platform is easily scalable because the marginal cost of a new student is very low [50]. The value creation potential of the institution is significant if it succeeds in raising the student volume on the platform [11].

\subsection{What Was the Impact of the Online Business Model in Terms of Applicants (RQ2)?}

In the years leading up to 2011, the business school at Campus Alta noticed a decrease in the number of applicants for some campus programs, and management discussed strategic measures to reverse the trend. At the same time, the need for distance education was just as important. Previously, the school would have established an offer in a municipality and travelled there physically to teach. It was decided, however, to apply what staff had already learned about online teaching to fuel growth. In the autumn of 2012, a web-based topic on business management was launched. Even though the program was only locally marketed, 48 people applied for a study permit. A year later, the program was announced nationally, and no less than 190 students applied for admission. The school had, for several years, operated a one-year business economics course with an annual admission of about 15-20 students. This course also went fully online in 2014. The demand grew from 65 students and gradually to 235 students during admission in 2019. The ever-larger bars and the exponential trend line plotted in Figure 1 illustrates the strong growth in number of applicants on online topics in recent years. The information in Figure 1 is based on secondary data from administrative systems of the business school.

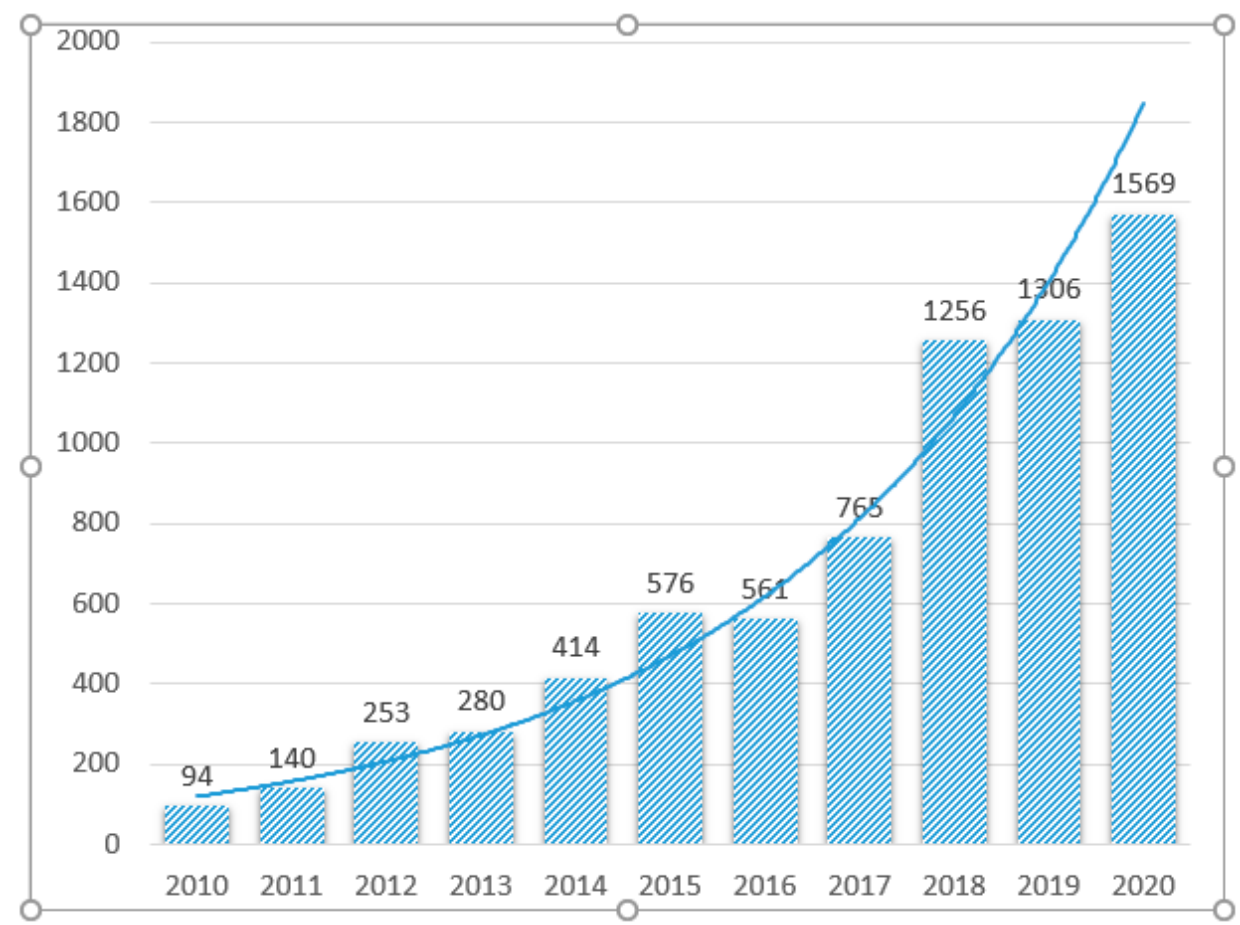

Figure 1. Number of online applicants at Campus Alta in recent years. 


\subsection{What Caused the Rising Number of Online Applicants (RQ3)?}

In free text, students could explain why they chose to study online. Table 2 lists an excerpt of answers.

Table 2. Why was it attractive for you to study online?

\begin{tabular}{|c|c|}
\hline Motive & The Students Explain \\
\hline Work flexibility & $\begin{array}{l}\text { "Can't attend lectures for the sake of my job." "Because I'm also working } \\
\text { and I need flexibility." "Can manage my own everyday life in relation to } \\
\text { work." "Works } 100 \% \text {, this is the only opportunity for me to study." }\end{array}$ \\
\hline Family flexibility & "Can combine studies, family and work." \\
\hline Place of residence flexibility & $\begin{array}{l}\text { "I don't have to spend time traveling." "I'm living in the district, have two } \\
\text { children and am on maternity leave. Then it's great with online studies." } \\
\text { "Because I don't want to leave my hometown. Due to residency, online } \\
\text { study is the only alternative." "I live far away from UiT campuses and also } \\
\text { like the flexibility it provides." "Don't want to move." "Live very remotely } \\
\text { and run a farm with my cohabitant." "Out of the question with other than } \\
\text { online studies." }\end{array}$ \\
\hline Economic flexibility & “Need money and have to work to cope." \\
\hline Time flexibility & $\begin{array}{l}\text { "I want to dispose of the time myself and not have to attend lectures." "It is } \\
\text { easier for me with ADHD to pause lectures when I need to." "Easy to follow } \\
\text { as you do not have to attend lectures, but can watch it at any time." }\end{array}$ \\
\hline Knowledge need & $\begin{array}{l}\text { "Works with several projects that require expertise in project management." } \\
\text { "When you have } 100 \% \text { job, this is the only way to study." "Further } \\
\text { development." "Need professional refill to avoid quitting my job." "To gain } \\
\text { additional expertise without having to quit the job." "Want to take a new } \\
\text { degree while still working." "Need formal expertise in the field." }\end{array}$ \\
\hline
\end{tabular}

Table 2 shows that there are different types of flexibility combined with a need of more formal knowledge that are the dominant motives for choosing an online learning. An approximately equal proportion of women $(81.6 \%)$ and men $(80.6 \%)$ pointed out the need for flexibility as the main reason why they chose to study online. There was also no difference between younger (less than 38 years) and older students when it came to emphasize the need for flexibility as the most important reason for choosing to study online ( $85.1 \%$ for students younger than 38 years and $83.7 \%$ for older students).

\subsection{Was There a Secondary Cannibalization Effect of the Online Business Model (RQ4)?}

The essence of a business model is to define how a business can create value for customers, get customers to pay for their values, and convert these payments into profits [14]. However, if a share of the value creation of the online business model is captured from the campus model, this becomes an opportunity cost of the new model. If this cost is considerable, the net value creation can be marginal, and in the worst case, negative [51]. On an empirical basis, a significant aim of this study is to examine whether online studies cannibalize traditional campus studies. Thus, it is assumed that if online studies address the same groups of students as campus studies, the former will potentially cannibalize the latter and make the dual business model unsustainable.

In the survey that was completed, a number of demographic data was collected about the students. Table 3 shows the gender, age, place of residence, percentage of full-time equivalent, and educational background for 80 online students at Campus Alta, which were enrolled and participated in the survey. In addition, the right column of the table contains information on gender, age, and place of residence for all campus students at UiT School of Business and Economics.

According to Table 3, 63\% of the online students were women compared with $43 \%$ on campus. The table shows that the age group $25-30$ is best represented online (30\%), while the group 19-24 is the largest on campus (73\%). Most online students (55\%), were however, more than 30 years (group 31-60 summed up) compared with $12 \%$ on campus. More than half of the online students of Campus Alta live in the Arctic or in the northern part of Norway (53\%), about one-third in central Norway (Østlandet), and the remaining in the rest of the country. In comparison, $94 \%$ of the campus students 
live in the north. Moreover, $63 \%$ of the students were in full-time jobs, and $11 \%$ studied full-time. A total of $23 \%$ of the online students worked part-time with different job percentages. Table 3 also shows that the online students were already well educated when they started online studies. A total of $69 \%$ $(48 \%+21 \%)$ had a formal academic degree before joining online studies. Based on the information in Table 3, it seems reasonable to conclude that the two business models address different study groups, and thus do not cannibalize each other.

Table 3. Demographic information of the online sample versus campus students.

\begin{tabular}{|c|c|c|c|}
\hline & & $\begin{array}{l}\text { Online } \\
(n=80)\end{array}$ & $\begin{array}{l}\text { All (Four) Campuses of School of } \\
\text { Business and Economics }(n=281)^{1}\end{array}$ \\
\hline \multicolumn{2}{|c|}{ Proportion of women } & $63 \%$ & $43 \%$ \\
\hline \multirow{7}{*}{ Age (years) } & $19-24$ & $15 \%$ & $73 \%$ \\
\hline & $25-30$ & $30 \%$ & $1 \%$ \\
\hline & $31-36$ & $16 \%$ & $6 \%$ \\
\hline & $37-42$ & $13 \%$ & $3 \%$ \\
\hline & $43-48$ & $13 \%$ & $2 \%$ \\
\hline & $49-54$ & $8 \%$ & $1 \%$ \\
\hline & $55-60$ & $5 \%$ & $0 \%$ \\
\hline \multirow{5}{*}{ Place of residence } & Finnmark (Arctic Norway) & $20 \%$ & $20 \%$ \\
\hline & Troms (Arctic Norway) & $20 \%$ & $63 \%$ \\
\hline & Nordland (north of Norway) & $13 \%$ & $11 \%$ \\
\hline & Central Norway (Østlandet) & $34 \%$ & $4 \%$ \\
\hline & Rest of the country & $13 \%$ & $2 \%$ \\
\hline \multirow{6}{*}{$\begin{array}{l}\text { Percentage of full-time } \\
\text { equivalent }\end{array}$} & Ca $0 \%$ & $11 \%$ & N/A \\
\hline & Ca $25 \%$ & $6 \%$ & N/A \\
\hline & Ca. $50 \%$ & $9 \%$ & N/A \\
\hline & Ca. $75 \%$ & $8 \%$ & N/A \\
\hline & Full-time job & $63 \%$ & N/A \\
\hline & Other & $3 \%$ & N/A \\
\hline \multirow{5}{*}{ Educational background } & $\begin{array}{l}\text { General university and college } \\
\text { admission certification }\end{array}$ & $15 \%$ & $\mathrm{~N} / \mathrm{A}$ \\
\hline & Real (nonformal) competence & $10 \%$ & N/A \\
\hline & Bachelor's degree & $48 \%$ & N/A \\
\hline & Master's degree & $21 \%$ & N/A \\
\hline & Other formal education & $6 \%$ & N/A \\
\hline
\end{tabular}

${ }^{1} 2018$ data. The abbreviation N/A means not available.

To gain further insight into why someone chose to study online, the follow-up questions in Table 4 were asked.

Table 4. What other education options did you consider?

\begin{tabular}{cc}
\hline \multicolumn{2}{c}{ Proportion $(\boldsymbol{n}=\mathbf{8 0})$} \\
\hline I would have chosen another online education & $55 \%$ \\
I would have chosen an education as a campus student & $9 \%$ \\
I would have studied, but not at a university & $1 \%$ \\
I would not have studied at all & $31 \%$ \\
Other & $4 \%$ \\
\hline
\end{tabular}

Table 4 shows that $55 \%$ of the respondents would have chosen another online education if their education choice had not been available. Moreover, $31 \%$ of the candidates claim that they would not have studied at all, and only $9 \%$ would have chosen to study on campus.

\section{Discussion}

The staff at Campus Alta has for years built and implemented an online business model, which has recruited online students in the local and national market for economic and management studies. The online model was implemented in parallel with the traditional campus model and has served as the key driver of the growth strategy of the business school. This interventionist action research case study 
started with describing key elements of the online business model (the intervention) at Campus Alta (RQ1). Next, the study examined the effect or impact of the intervention in terms of online applicants in the last decade (RQ2). Thereafter, what caused the rising number of online applicants (i.e., the effect of the intervention) was investigated (RQ3). Finally, the study explored if the intervention has caused a secondary cannibalization effect on the traditional campus studies (RQ4) and thus making the dual business model less sustainable. The paper will now discuss the findings in the same order as the research questions. Several of the strategic insights gained are hopefully relevant to other institutions that want to, or feel compelled to, compete with a dual business model in the future.

As a response to RQ1, the empirical part of this study started by describing key elements of the online business model implemented at Campus Alta (see Table 1). Changing a business model is, however, expensive and demanding [40]. The institution must be reasonably confident that the new model will solve the problems of students in a better way than the old model, which was characterized by being too inflexible. Moreover, the new model must also add value to the institution in terms of growth and value creation. If unmet needs for flexibility are materializing in the education market, or threatening digital competitors emerge on the horizon, these will be important drivers for the decision to implement an online model. Ultimately, the management has to decide whether it is worth the money and the effort to invest in an online business model [52]. Nevertheless, when the traditional campus model no longer meets the need of core student groups, the time is right to implement an online business model. Campus Alta has retained its traditional campus model, even though it developed an online model. The two models therefore exist side by side, and together, they constitute a dual complementing business model for the institution [27].

The online business model was a core element in the growth strategy of the institution, and the second research question raised (RQ2) was how much growth the online business model had been able to create in recent years. Figure 1 discloses that the model indeed underpinned the growth strategy of the business school, and in retrospect, the strong student influx indicates that the decision to offer online subjects was strategically correct. Moreover, half of the online learners lived in southern Norway (see Table 3), which was an unintended consequence of the offer. It strengthens the legitimacy and credibility of the model that it also has a national footprint [9]. Furthermore, from strategy literature, it is known that organizations that create new paths also may need luck to be successful [53]. The success of Campus Alta is probably both rooted in the faculty's capability in turning disadvantages (such as a large geographical area, a small population, and a less research-intensive institution) into advantages; and in addition, they may have had luck with the timing.

Thirdly, this study investigated what attracted students to enroll in online classes (RQ3). The students attending the online courses received recognized European Credit Transfer credits, which is a standard for comparing the volume of learning based on defined learning outcomes and their associated workload across the European Union. In the model described (see Table 1), both online and campus students had the same curriculum and the same exam. These aspects strengthened the legitimacy of the model [54] and enabled the school to counter claims that online studies are a shortcut to "cheap" credits [55]. Online students can take their exams at three geographically dispersed study centers in Norway, five campus locations, and in addition, the capital city of Oslo.

Furthermore, faculty is central to planned change in higher education [56]. The staff at Campus Alta realized more than ten years ago the limitations of the traditional campus model when it came to satisfying the social mission of their education. They could no longer require that students in a geographically large and sparsely populated area always entered campus to attend classes there. Instead, the institution itself had to try to reach out to the students where they lived. However, meeting them all physically would be too costly. To address the changing needs of students, the solution was to meet online. This was the central motive behind the process that led to the development of online business studies in Arctic Norway. This study shows that the online business model that has been implemented has provided students with the flexibility they needed (see Table 2). Students point out the need to gain knowledge flexibly as most central when explaining what is attractive about online 
learning. This kind of flexibility is not on offer in traditional campus studies. Accordingly, the value proposition of the traditional model did not deliver what was needed for large and growing groups of students in Arctic Norway [14,40].

As Campus Alta has implemented a dual business model, the fourth research question raised (RQ4) was whether the online business model cannibalized campus studies. If competing, students switching from campus to the web is an opportunity cost of online studies that makes them less sustainable. To examine this question, the study first asked what characterizes those persons who had chosen to study online (Table 3). The age distribution shows that it is not primarily first timers who start online studies. The students, on the contrary, are adults in that more than half of them are more than 30 years old, and more than one in four are above the age of 42 . Most of them live in northern Norway, and one-third is located in central Norway. Only $11 \%$ of them studied full-time, and $63 \%$ were in full-time jobs.

The online learners are thus adults who study full-time or part-time, and they live all over the country. A total of $69 \%$ had a Bachelor's or Master's degree when they started studying. Thus, they bring a solid academic ballast into their online studies. The results also show that online studies are a central channel of lifelong learning for people at work. This is completely in line with the ambitions of the Norwegian white paper "Quality Culture in Higher education" [8]. Another key finding is the importance of online studies for women, because almost two out of three students are female. Especially for women in paid work, with family commitments and who live far from campus, the flexibility offered by online studies is precisely what they need to further develop professionally in their jobs (see Table 2). This finding is in line with rural education researchers who have found that women are significantly more successful in formal education than their male counterparts [57]. The finding also supports Peter and Horn [58] who found that mature (over 40) single-parent, and low-income women have become the largest group among adult learners. Family and community obligations often do not allow them to enroll in conventional college programs. However, online courses meet this student group's need for access, flexibility, and convenience as uncovered in Table 2 of the present study.

Furthermore, relevance is a key quality indicator of a study [59]. Based on the results in Table 4, students experienced online studies as relevant. A total of $31 \%$ would not have studied at all if it were not for online studies, and only $9 \%$ would have chosen to study on campus. Online students are thus on a different learning path than the younger campus students. Against this backdrop, it is reasonable to conclude that online students do not cannibalize the basis for campus studies as the two models reach out to different target groups. Online studies are absolutely central to the social mission of the school, which is to meet the region's need for higher education. Thus, this study shows that online studies have proven essential for the institution to fulfill its social sustainability goal [60], which is at the core of its mission (see Section 3.1). Online education is in addition to, and not a replacement for, the campus offer. It also contributes to an overall stronger academic environment on campus. The two models thus complement and create synergies for each other, which strengthens the sustainability of both models.

\section{Implications}

When Campus Alta established its online studies, it quickly became apparent there was a need for online learning not just in Finnmark, but throughout the country (see Figure 1 and Table 3). The limited recruitment base and the geographical distance disadvantage of Campus Alta forced the academic community to be quick in launching an online business model. In this way, the large and sparsely populated region, which was basically a drawback for the institution, turned into a rural competitive advantage through their digitalization strategy.

From the literature, it is known that the first company that implements a strategy in an industry can gain a first-mover advantage over its competitors [61]. This can occur, for example, by the company accruing goodwill with its customers and by developing a positive reputation. The first company will also be in the best position to trim operating costs through learning [62]. If, however, similar firms are 
able to implement similar strategies, the first will only have a temporary advantage [24]. It is thus not certain that the online business model of Campus Alta is so well established in the Norwegian online learning market that it provides a lasting competitive advantage. However, it is gratis for students to take a web course in the same way as a campus topic. It is therefore difficult for intruders to outperform Campus Alta on price. In that case, the competition will be focused on quality (differentiation) [63].

Most academic staff at universities have a doctorate, and they have developed a strong research identity [64]. It is not certain that these people are willing to change their teaching role toward online studies [65]. In that case, smaller and less research-intensive and more student-focused institutions can develop an advantage in the online education market. The most significant people in the implementation of the online business model at Campus Alta belong precisely to this last category [66]. They have also developed a strong identity with the region. The Arctic region needs success stories badly. If they succeed with online studies, this will be noticed in the town and throughout Finnmark. The motivation among the employees to put in considerable extra effort for the community will therefore be great. Precisely this driving force can give them a rare and valuable advantage that is difficult to imitate [24]. Accordingly, it is more likely that the research-intensive institutions will continue in their locked-in historical pedagogical and strategic paths $[67,68]$.

The traditional UiT university organization is primarily built to provide campus services. Neither technical assistance nor administrative systems are specifically designed for online teaching and online learning. After Finnmark University College was merged with UiT, there has been more bureaucracy for the development team and a longer distance to key decision-makers [66]. It is uncertain whether traditional university organizations are flexible enough to establish cost-effective online studies and compete based on a dual business model [16]. When the strategy of an organization develops in incremental steps [69], it risks getting out of touch with the (digital) environment [52]. For the management, it can be tempting to push the problems under the carpet [70]. However, this can have disastrous consequences for organizations in the long run [71]. Nevertheless, the external shock inflicted on higher education by the Corona crisis this winter/spring, has the potential to become an ice-breaker for online studies worldwide because of the superior flexibility this business model has been demonstrating.

\subsection{Limitations}

Participant research involves active engagement of the researchers in the case being studied to the extent that it influences the activities and discourses that occur [72]. The core criticism of the participant researcher is that the proximity of the investigator to the situation being researched can cause biased collection, interpretation, and/or reporting [73]. In the present study, these issues were approached by drawing the viewpoints, motives, and background for conducting the research into the analysis and by integrating it into existing theory as outlined in the previous sections of this paper. From this perspective, the fact that the research was based upon a real intervention in the field and was conducted by teachers and managers who have improved their practice through a methodological approach to research and development, is a potentially valuable aspect of the study [74].

\subsection{Future Research}

Campus Alta which has introduced the dual business model discussed in this study is separated geographically from the three other campuses of the business school. However, the online business model is integrated with the campus model at this specific campus. This integration lays the foundation for exploiting synergies between the two models [18]. However, the integrated approach also highlights that the models sometimes compete [20], not for the same students, but for the same financial and human resources that are needed to deliver quality education regardless of the model. A future research and development project can therefore be to separate the online business model into a 'pure' virtual campus. The virtual campus can next be linked organizationally with all four physical campuses by hiring key personnel temporally as needed. At the same time, the digital learning resources developed 
by the virtual campus can be distributed to all physical campuses and enable them to develop high in-demand blended learning activities cost effectively. With these kinds of organizational links and transactions, synergies can be made more visible and contribute to even greater legitimacy of the online business model. Future research should study the temporal and contextual exploration and exploitation activities between dual business models to gain better insight into when to do what, as this is in high demand $[18,75]$.

Funding: This research received no external funding. The publication charges for this manuscript have been funded by a grant from the publication fund of UiT The Arctic University of Norway.

Acknowledgments: The following practitioners and enthusiasts at Campus Alta have been key people in developing and implementing the online business model discussed in this study: General manager, Jørund Greibrokk; teacher and developer of online studies, Egil Rasmussen; and administrator responsible for online studies, Pål Einar Lund. They also served as critical informants in this study.

Conflicts of Interest: The author declares no conflict of interest.

\section{References}

1. Anderson, L.; Hibbert, P.; Mason, K.; Rivers, C. Management Education in Turbulent Times. J. Manag. Educ. 2018, 42, 423-440. [CrossRef]

2. Kumar, P.; Kumar, A.; Palvia, S.; Verma, S. Online business education research: Systematic analysis and a conceptual model. Int. J. Educ. Manag. 2019, 17, 26-35. [CrossRef]

3. Seaman, J.E.; Allen, I.E.; Seaman, J. Grade Increase: Tracking Distance Education in the United States; The Babson Survey Research Group: Wellesley, MA, USA, 2018.

4. Thomas, D.R. Digital Disruption: A Transformation in Graduate Management Online Education. In Phantom Ex Machina; Springer International Publishing: New York, NY, USA, 2017; pp. 223-233. [CrossRef]

5. Choy, S. Benefits of e-learning benchmarks: Australian case studies. Electron. J. E Learn. 2007, 5, 11-20.

6. Collis, B.; Moonen, J. Flexible Learning in a Digital World: Experiences and Expectations; Kogan-Page: London, $\mathrm{UK}, 2001$.

7. Means, B.; Toyama, Y.; Murphy, R.; Bakia, M.; Jones, K. Evaluation of Evidence-Based Practices in Online Learning: A Meta-Analysis and Review of Online Learning Studies; Department of Education: Washington, DC, USA, 2010.

8. Meld. St. 16. 2016-2017. Quality Culture in Higher Education. Available online: https://www.regjeringen. no/no/dokumenter/meld.-st.-16-20162017/id2536007/ (accessed on 20 May 2020).

9. KD. National Competence Policy Strategy 2017-2021. Available online: https://www.regjeringen.no/no/ dokumenter/nks/id2527271/ (accessed on 20 May 2020).

10. Yuan, L.; Powell, S.; Cetis, J. MOOCs and Open Education: Implications for Higher Education. JISC CETIS White Paper. Available online: http://publications.cetis.ac.uk/2013/667 (accessed on 14 May 2020).

11. Cohen, B.; Kietzmann, J. Ride on! Mobility business models for the sharing economy. Organ. Environ. 2014, 27, 279-296. [CrossRef]

12. Martins, L.L.; Rindova, V.P.; Greenbaum, B.E. Unlocking the hidden value of concepts: A cognitive approach to business model innovation. Strateg. Entrepreneurship J. 2015, 9, 99-117. [CrossRef]

13. Zott, C.; Amit, R. Business model design: An activity system perspective. Long Range Plan. 2010, 43, 216-226. [CrossRef]

14. Teece, D.J. Business models, business strategy and innovation. Long Range Plan. 2010, 43, 172-194. [CrossRef]

15. Richardson, J. The business model: An integrative framework for strategy execution. Strateg. Chang. 2008, 17, 133-144. [CrossRef]

16. Markides, C.; Charitou, C.D. Competing with dual business models: A contingency approach. Acad. Manag. Perspect. 2004, 18, 22-36. [CrossRef]

17. Markides, C.; Oyon, D. What to do against disruptive business models (when and how to play two games at once). MIT Sloan Manag. Rev. 2010, 51, 25.

18. Markides, C. Business model innovation: What can the ambidexterity literature teach us? Acad. Manag. Perspect. 2013, 27, 313-323. [CrossRef]

19. Porter, M. What is strategy? Harv. Bus. Rev. 1996, 74, 61-78. 
20. Aversa, P.; Haefliger, S.; Reza, D.G. Building a winning business model portfolio. MIT Sloan Manag. Rev. 2017, 58, 49-54.

21. Casadesus-Masanell, R.; Tarzijan, J. When one business model is not enough. Harv. Bus. Rev. 2012, 90, 132-137.

22. Sabatier, V.; Mangematin, V.; Rousselle, T. From recipe to dinner: Business model portfolios in the European biopharmaceutical industry. Long Range Plan. 2010, 43, 431-447. [CrossRef]

23. Fréry, F.; Lecocq, X.; Warnier, V. Competing with ordinary resources. MIT Sloan Manag. Rev. 2015, 56, 69.

24. Barney, J.B. Firm resources and sustained competitive advantage. J. Manag. 1991, 17, 99-120. [CrossRef]

25. Peteraf, M.A. The cornerstones of competitive advantage: A resource-based view. Strateg. Manag. J. 1993, 14, 179-191. [CrossRef]

26. Wernerfelt, B. A resource-based view of the firm. Strateg. Manag. J. 1984, 5, 171-180. [CrossRef]

27. Baden-Fuller, C.; Haefliger, S. Business models and technological innovation. Long Range Plan. 2013, 46, 419-426. [CrossRef]

28. Liu, Y.; Green, A.; Pensiero, N. Expansion of higher education and inequality of opportunities: A cross-national analysis. J. High. Educ. Policy Manag. 2016, 38, 242-263. [CrossRef]

29. Charbonneau-Gowdy, P. It Takes a Community to Develop a Teacher: Testing a New Teacher Education Model for Promoting ICT in Classroom Teaching Practices in Chile. Electron. J. E Learn 2015, 13, 237-249.

30. Kotter, J.P. Leading change: Why transformation efforts fail. Harv. Bus. Rev. 1995, 73, 56-67. [CrossRef]

31. UiT Strategy 2009-2013 (n.d.). Available online: https://uit.no/Content/143103/Strategi.pdf (accessed on 24 May 2020).

32. UiT Flexible Education (n.d). Available online: https://uit.no/prosjekter/prosjekt?p_document_id=245068 (accessed on 24 May 2020).

33. Yin, R.K. Case Study Research: Design and Methods; Sage publications: Newsbury Park, CA, USA, 2014.

34. Jönsson, S.; Lukka, K. There and Back Again: Doing Interventionist Research in Management Accounting. In Handbook of Management Accounting Research; Chapman, C.S., Hopwood, A.G., Shields, M.D., Eds.; Elsevier: Oxford, UK, 2007; Volume 1, pp. 373-397. [CrossRef]

35. Argyris, C.; Putnam, R.; Smith, D.M. Action Science; Jossey-Bass: San Francisco, CA, USA, 1985.

36. Westin, O.; Roberts, H. Interventionist research-the puberty years: An introduction to the special issue. QRAM 2010, 7, 5-12. [CrossRef]

37. Carkhuff, R.R. Productive Problem Solving; Human Resource Development Press: Amherst, MA, USA, 1985.

38. Thomas, E.J.; Rothman, J. An Integrative Perspective on Intervention Research. In Intervention Research: Design and Development for the Human Services; Rothman, J., Thomas, E.J., Eds.; Haworth: New York, NY, US, 1994; pp. 3-20.

39. Johnson, R.B.; Onwuegbuzie, A.J. Mixed methods research: A research paradigm whose time has come. Educ. Res. 2004, 33, 14-26. [CrossRef]

40. Johnson, M.W.; Christensen, C.M.; Kagermann, H. Reinventing your business model. Harv. Bus. Rev. 2008, $86,57-68$.

41. Deming, D.J.; Goldin, C.; Katz, L.F.; Yuchtman, N. Can online learning bend the higher education cost curve? Am. Econ. Rev. 2015, 105, 496-501. [CrossRef]

42. Ahmed, H.M.S. Hybrid E-Learning acceptance model: Learner perceptions. Decis. Sci. J. Innov. Educ. 2010, 8, 313-346. [CrossRef]

43. Freeze, R.D.; Alshare, K.A.; Lane, P.L.; Wen, H.J. IS Success Model in E-learning Context based on Students' Perceptions. J. Inf. Syst. Educ. 2010, 21, 173-184.

44. Black, P.; Wiliam, D. Developing the theory of formative assessment. Educ. Assess. Eval. Account. 2009, 21, 5-31. [CrossRef]

45. Beech, N.; MacIntosh, R.; MacLean, D. Dialogues between academics and practitioners: The role of generative dialogic encounters. Organ. Stud. 2010, 31, 1341-1367. [CrossRef]

46. Bertheussen, B.A.; Myrland, $\varnothing$. Relation between academic performance and students' engagement in digital learning activities. J. Educ. Bus. 2016, 91,1-7. [CrossRef]

47. Noe, R.A.; Tews, M.J.; McConnell Dachner, A. Learner engagement: A new perspective for enhancing our understanding of learner motivation and workplace learning. Acad. Manag. Ann. 2010, 4, 279-315. [CrossRef]

48. Biggs, J. Enhancing teaching through constructive alignment. High. Educ. 1996, 32, 347-364. [CrossRef] 
49. Daniel, J.; Cano, E.V.; Cervera, M.G. The future of MOOCs: Adaptive learning or business model? Int. J. Educ. Technol. High. Educ. 2015, 12, 64-73. [CrossRef]

50. Amit, R.; Zott, C. Creating value through business model innovation. MIT Sloan Manag. Rev. 2012, 53, 41-49.

51. Pertusa-Ortega, E.M.; Molina-Azorín, J.F.; Claver-Cortés, E. Competitive strategies and firm performance: A comparative analysis of pure, hybrid and 'stuck-in-the-middle'strategies in Spanish firms. Br. J. Manag. 2009, 20, 508-523. [CrossRef]

52. Arthur, W.B. Competing technologies, increasing returns, and lock-in by historical events. Econ. J. 1989, 99, 116-131. [CrossRef]

53. Barney, J.B. Strategic factor markets: Expectations, luck, and business strategy. Manag. Sci. 1986, 32, 1231-1241. [CrossRef]

54. Suchman, M.C. Managing legitimacy: Strategic and institutional approaches. Acad. Manag. Rev. 1995, 20, 571-610. [CrossRef]

55. Milani, M. Cultural Impact on Online Education Quality Perception. Electron. J. E Learn. 2008, 6, 149-160.

56. Mitchell, L.D.; Parlamis, J.D.; Claiborne, S.A. Overcoming faculty avoidance of online education: From resistance to support to active participation. J. Manag. Educ. 2015, 39, 350-371. [CrossRef]

57. Corbett, M. All kinds of potential: Women and outmigration in an Atlantic Canadian coastal community. J. Rural Stud. 2007, 23, 430-442. [CrossRef]

58. Peter, K.; Horn, L. Gender Differences in Participation and Completion of Undergraduate Education and How They have Changed Over Time; US Department of Education (NCES): Washington, DC, USA, 2005. Available online: http://nces.ed.gov/pubs2005/2005169.pdf (accessed on 9 June 2020).

59. Bertheussen, B.A. Hvordan kan handelshøyskolene gjenvinne relevans? Magma 2017, 20, 46-54.

60. Cuthill, M. Strengthening the 'social'in sustainable development: Developing a conceptual framework for social sustainability in a rapid urban growth region in Australia. Sustain. Dev. 2010, 18, 362-373. [CrossRef]

61. Lieberman, M.B.; Montgomery, D.B. First-mover advantages. Strateg. Manag. J. 1988, 9, 41-58. [CrossRef]

62. Yelle, L.E. The learning curve: Historical review and comprehensive survey. Decis. Sci. 1979, 10, 302-328. [CrossRef]

63. Porter, M. Competitive Strategy; The Free Press/Macmillan: New York, NY, USA, 1980.

64. Reybold, L.E. Pathways to the professorate: The development of faculty identity in education. Innov. High. Educ. 2003, 27, 235-252. [CrossRef]

65. Allen, I.E.; Seaman, J. Online Report Card: Tracking Online Education in the United States; Babson Survey Research Group: Wellesley, MA, USA, 2016.

66. Bertheussen, B.A.; Greibrokk, J.; Rasmussen, E.; Lund, P.E. Høyere utdanning i omstilling: Erfaringer med nettstudier i økonomi og ledelse. Magma 2019, 22, 46-52.

67. Bertheussen, B.A. Er handelshøyskolene innelåst i historiske pedagogiske spor? Magma 2013, 16, 40-48.

68. Park, N.K.; Mezias, J.M.; Song, J. A resource-based view of strategic alliances and firm value in the electronic marketplace. J. Manag. 2004, 30, 7-27. [CrossRef]

69. Johnson, G. Rethinking incrementalism. Strateg. Manag. J. 1988, 9, 75-91. [CrossRef]

70. Van de Ven, A.H. Central problems in the management of innovation. Manag. Sci. 1986, 32, $590-607$. [CrossRef]

71. Bennis, W.G.; O'Toole, J. How business schools lost their way. Harv. Bus. Rev. 2005, 83, 96-104.

72. Bertheussen, B.A. Improving Management Accounting Education through the use of Interventionist Action Research. Beta 2017, 2, 170-183. [CrossRef]

73. Guba, E.G.; Lincoln, Y.S. Competing paradigms in qualitative research. Handb. Qual. Res. 1994, 2, 105.

74. Gutiérrez, K.D.; Penuel, W.R. Relevance to practice as a criterion for rigor. Educ. Res. 2014, 43, 19-23. [CrossRef]

75. Birkinshaw, J.; Gupta, K. Clarifying the distinctive contribution of ambidexterity to the field of organization studies. Acad. Manag. Perspect. 2013, 27, 287-298. [CrossRef]

(C) 2020 by the author. Licensee MDPI, Basel, Switzerland. This article is an open access article distributed under the terms and conditions of the Creative Commons Attribution (CC BY) license (http://creativecommons.org/licenses/by/4.0/). 